\title{
A priority-driven, policy-relevant research program to support a response to blood- borne viruses and sexually transmissible infections in NSW, Australia
}

\section{Tina Gordon ${ }^{\mathrm{a}, \mathrm{b}}$, Cherie Power ${ }^{\mathrm{a}}$, Tim Duck ${ }^{\mathrm{a}}$, Heather-Marie A Schmidt ${ }^{\mathrm{a}}$ and Joanne Holdena}

a NSW Ministry of Health, Sydney, Australia

b Corresponding author: tina.gordon@health.nsw.gov.au

\section{Article history}

Publication date: September 2018 Citation: Gordon T, Power C, Duck T, Schmidt H-MA, Holden J. A priority-driven, policy-relevant research program to support a response to blood-borne viruses and sexually transmissible infections in NSW, Australia. Public Health Res Pract. 2018;28(3):e2831820. https://doi. org/10.17061/phrp2831820

\section{Key points}

- The BBV \& STI Research, Intervention and Strategic Evaluation Program (BRISE) is a New South Wales (NSW) Government-funded, university-based priority research program. It delivers policy-relevant research, strategic advice, capacity building and communications to support the response to blood-borne viruses (BBV) and sexually transmissible infections (STI) in NSW, Australia

- BRISE objectives are to facilitate the generation of policy-relevant research and increase the use of research in practice

- Strategies include flexible and collaborative research priority setting, making research more accessible and developing workforce capacity to utilise evidence

\section{Abstract}

Objectives: Strong collaboration between researchers, policy makers and practitioners supports the use of research evidence in policy and practice. Strategies for increasing the use of evidence in policy development and implementation include creating more opportunities for closer collaboration between researchers and policy makers, ensuring research syntheses are more accessible to policy makers, and increasing workforce capacity to utilise evidence.

Type of program or service: The BBV \& STI Research, Intervention and Strategic Evaluation Program, 2014-2019 (BRISE) is a coherent and integrated program that delivers policy-relevant research, strategic advice, capacity building and communications to support the response to bloodborne viruses (BBV) and sexually transmissible infections (STI) in New South Wales (NSW), Australia. BRISE has five key objectives: generate highquality research; maximise the use of research; build research capacity; communication and marketing; and governance and management.

Results: BRISE facilitates the coproduction of research where researchers and policy makers are meaningfully involved in all stages of research priority setting and codesign from development to application, building an understanding of the way evidence is generated to allow for greater integration between research and use of evidence.

Lessons learnt: Bringing multiple research projects together under a single contract and budget provided the NSW Ministry of Health (the Ministry) with cost efficiencies and streamlined contract management and project reporting. A flexible work plan allowed for a mix of longer-term (up to 5-year) projects and shorter projects that were responsive to emerging policyrelevant research priorities. The Ministry became involved in the production of collaborative research as a research partner, rather than solely a research 'funder'. The joint management of research projects involving a policy officer from the Ministry provided opportunities for individuals to build on their research capabilities and literacy. Collaborative priority setting and project work, and increased research literacy, improved the likelihood that research generated would then be used in policy and practice. 


\section{Introduction}

Conducting research to inform, improve and monitor government policy is a challenge for both policy makers and researchers. ${ }^{1-4}$ Policy-relevant research needs to be responsive to changing evidence and political landscapes, risks and opportunities; generate solutions; guide investment; and most importantly be aligned with and support the delivery of current government strategic goals. ${ }^{1,3,5}$ Studies suggest that the use of research in policy development and implementation may be encouraged by strategies such as enabling timely access to relevant research findings; encouraging interaction with researchers, including research partnerships and coproduction of research; and increasing individual and organisational capacity to use research. ${ }^{6-8}$

Close collaboration between research agencies and funders, such as government, have been shown to be effective in generating policy-relevant research, particularly where funders are involved in decisions that drive the strategic directions of the program to deliver on priority outcomes. ${ }^{9}$ Government-funded university research centres provide opportunities to facilitate ongoing exchange and collaboration in developing and implementing contemporary and effective policy research. ${ }^{1,5,8,9}$

\section{The role of the BBV \& STI Research, Intervention and Strategic Evaluation Program (BRISE)}

In 2013, the Centre for Population Health, New South Wales (NSW) Ministry of Health (the Ministry), commissioned a 5-year research program for bloodborne viruses (BBVs) and sexually transmissible infections (STIs), replacing the previous model of funding multiple research proposals separately under individual contracts. A joint submission from the Kirby Institute for infection and immunity in society and the Centre for Social Research in Health at UNSW Sydney was selected to establish the BBV \& STI Research, Intervention and Strategic Evaluation Program, 2014-2019 (BRISE).

BRISE is a coherent and integrated program based in NSW, Australia. BRISE generates BBV and STI policy-relevant research, provides strategic advice, undertakes capacity building, communicates research findings to guide efforts to improve the health of affected communities and priority populations, and strengthens the linkage of research and evidence with policy and practice.

Table 1. The BBV \& STI Research, Intervention and Strategic Evaluation Program (BRISE) objectives and examples of core functions

\begin{tabular}{|c|c|c|c|c|}
\hline $\begin{array}{l}\text { Objective 1: } \\
\text { Generate high-quality } \\
\text { research }\end{array}$ & $\begin{array}{l}\text { Objective } 2 \text { : } \\
\text { Maximise the use of } \\
\text { research }\end{array}$ & $\begin{array}{l}\text { Objective 3: } \\
\text { Build research } \\
\text { capacity }\end{array}$ & $\begin{array}{l}\text { Objective 4: } \\
\text { Communication and } \\
\text { marketing }\end{array}$ & $\begin{array}{l}\text { Objective 5: } \\
\text { Governance and } \\
\text { management }\end{array}$ \\
\hline $\begin{array}{l}\text { Significant evaluations } \\
\text { relevant to priority } \\
\text { policies and programs } \\
\text { linked to key NSW } \\
\text { strategies }\end{array}$ & $\begin{array}{l}\text { Annual research } \\
\text { updates on BBV } \\
\text { and STI prevention, } \\
\text { testing, treatment and } \\
\text { transmission in NSW }\end{array}$ & $\begin{array}{l}\text { Delivery of professional } \\
\text { development programs }\end{array}$ & $\begin{array}{l}\text { A range of reports } \\
\text { and peer-reviewed } \\
\text { publications published } \\
\text { and disseminated to the } \\
\text { Ministry }\end{array}$ & $\begin{array}{l}\text { Meetings of the Advisory } \\
\text { Board held biannually }\end{array}$ \\
\hline $\begin{array}{l}\text { Applied research and } \\
\text { quality improvement } \\
\text { projects; primary and } \\
\text { secondary research } \\
\text { projects }\end{array}$ & $\begin{array}{l}\text { Evidence synthesis } \\
\text { reports (e.g. reviews, } \\
\text { literature updates and } \\
\text { discussion papers) }\end{array}$ & $\begin{array}{l}\text { Evidence of collaboration } \\
\text { with a range of Local } \\
\text { Health Districts and } \\
\text { nongovernment } \\
\text { organisations on relevant } \\
\text { contract work }\end{array}$ & $\begin{array}{l}\text { Presentations at local, } \\
\text { national and international } \\
\text { conferences and } \\
\text { seminars }\end{array}$ & $\begin{array}{l}\text { Annual report and } \\
\text { quarterly work plan } \\
\text { meetings }\end{array}$ \\
\hline $\begin{array}{l}\text { Research advice } \\
\text { provided to the Ministry } \\
\text { for research, monitoring } \\
\text { and/or evaluation design }\end{array}$ & $\begin{array}{l}\text { Policy-relevant reports, } \\
\text { formal expert advice, } \\
\text { as requested by the } \\
\text { Ministry }\end{array}$ & $\begin{array}{l}\text { Reports on significant } \\
\text { monitoring and } \\
\text { evaluation projects }\end{array}$ & $\begin{array}{l}\text { Production of a range of } \\
\text { publications including } \\
\text { plain-English summaries } \\
\text { and fact sheets for target } \\
\text { audiences }\end{array}$ & $\begin{array}{l}\text { Strategic plan updated } \\
\text { annually }\end{array}$ \\
\hline
\end{tabular}

NSW = New South Wales; Ministry = NSW Ministry of Health; BBV = blood-borne virus; STI = sexually transmissible infection 
The Ministry and the BRISE Secretariat jointly manage a single contract and budget, which supports improved management and efficiency in purchasing and planning. The BRISE Advisory Board has member representation from each of the contracted parties (the Ministry, Kirby Institute and Centre for Social Research in Health), community organisations, sexual health directors, the Aboriginal Health \& Medical Research Council, NSW state-wide services and Local Health Districts.

BRISE has five key objectives, developed by the Ministry in line with the NSW Health strategy Promoting the generation and effective use of population health research in NSW: a strategy for NSW Health 2011-2015 (policy updated in 2018): 10,11

- Generate high-quality research

- Maximise the use of research

- Build research capacity

Communication and marketing

- Governance and management.

BRISE delivers a number of core functions under each key objective. Examples of core functions are outlined in Table 1 (see page 2). Deliverables against core functions are embedded in the annual work plan to guide program delivery.

\section{Collaborative production of}

\section{research}

Collaborative priority setting for policy-relevant research is a key feature of BRISE. The first annual BRISE work plan was developed through an iterative process of collaborative consultation and review, within a statewide policy priority framework. Forums were held over 2 days with key stakeholders including nongovernment organisations, Local Health Districts, clinicians, academics and policy makers to determine research priorities to address NSW BBV and STI service priorities. Priorities identified through this process were graded by policy relevance, impact and urgency. Results of the consultation were cross-referenced by the Ministry against priorities in each of the NSW BBV and STI Strategies and the Aboriginal BBV and STI Framework. ${ }^{12-16}$ A collaborative approach for setting the first work plan increased the likelihood that research outputs would be coproduced, policy aligned, timely and used in practice. ${ }^{4}$

The work plan is reviewed quarterly, which provides flexibility and allows a mix of longer-term (up to 5-year) projects to be implemented alongside new deliverables that are responsive to emerging policy-relevant research priorities. Examples of activities within an annual work plan can be found in Table 2. The table shows the mix and spread of work that supports program objectives, and outlines how the research has been used in practice.

BRISE is entering the final year of the 5-year contract. A review will be undertaken to explore stakeholders' perceptions, learnings and challenges encountered in the delivery of the program.

\section{Maximising the use of policy- relevant research}

Strategies for increasing the use of evidence in policy development and implementation include creating more opportunities for closer collaboration between researchers and policy makers, ensuring research syntheses are more accessible to policy makers, and increasing workforce capacity to utilise evidence. ${ }^{5,7}$

BRISE activities engage a range of researchers with experience in HIV, STI or viral hepatitis, with each BRISE research project being jointly managed by a policy officer from the Ministry. All projects are overseen by a project committee including organisations who represent affected communities and clinicians where appropriate. This structure provides an opportunity for policy officers to codesign the research project from development to application, building a closer understanding of the way evidence is generated to allow for a greater integration between research and use of evidence.

Types of research outputs and how they are communicated affect their accessibility and determine their use by policy makers. ${ }^{6,8}$ BRISE reports and research findings are disseminated through a wide range of mediums, including through traditional academic routes of peer-reviewed academic journals and conference presentations. The BRISE website hosts a list of projects and publicly available reports (www.brise.com.au/ projects). Each year BRISE hosts a series of interactive symposiums with practitioners and policy makers to showcase research and how it is being used in practice. Over the course of the program, the format of the symposiums has changed from face-to-face delivery to topic-specific webinars to increase the reach of the showcases.

The Estimates and Projections of the Hepatitis C Virus Epidemic in NSW project is an example of setting policy-driven research priorities. To support the implementation of the NSW Hepatitis C Strategy 20142020, the Ministry needed to develop targets to monitor hepatitis $\mathrm{C}$ treatment uptake and coverage in NSW. BRISE researchers produced estimates for hepatitis C prevalence, incidence and morbidities in NSW by Local Health District over 2016-2030, and identified annual treatment targets required for each Local Health District to achieve the strategy goal of hepatitis $\mathrm{C}$ elimination by 2028. ${ }^{19}$

The estimates and projections were used by the Ministry to develop key performance indicators in Local Health District Service Agreements and the NSW Safety and Quality Framework. Reporting mechanisms allow the Ministry to monitor progress against the hepatitis C treatment targets, and provide quarterly reports to Local Health Districts to inform their efforts to increase testing and treatment.

The NSW Sexual Health Promotion Framework was developed in 2015 to support the achievement of the 
Table 2. Examples of projects and activities of the BBV \& STI Research, Intervention and Strategic Evaluation Program (BRISE)

\section{BRISE research objective/ policy priority}

Applied research and quality improvement projects

Applied research and quality improvement projects

Primary and secondary research projects

Primary and secondary research projects

Policy-relevant reports, formal expert advice, as requested by the Ministry

Delivery of a professional development program

\section{A range of reports} and peer-reviewed publications published and disseminated to the Ministry

Annual report and quarterly work plan meetings

\section{Project/activity}

The NSW Needle and Syringe Program Enhanced Data Collection Report ${ }^{17}$ - an annual snapshot of key demographic and drug use behaviour of clients attending needle and syringe programs.

StraightMSM Study: understanding expert views on defining and reaching heterosexually identified men who have sex with men for health promotion and care $^{18}$ - formative research that explores the sexual practice and self-identity of heterosexually identified men who have sex with men ('straight MSM'), and discusses the challenges of reaching this group in the sexual health and HIV sectors.

2017 estimates and projections of the hepatitis C virus epidemic in NSW ${ }^{19}$ - mathematical modelling to develop benchmarks which guide effort and measure success for hepatitis $C$ elimination in NSW.

PrEPARE Study ${ }^{20}$ - monitoring behaviour and attitude change in men who have sex with men in relation to biomedical HIV prevention and treatment as prevention.

Provision of surveillance data and expert advice for: quarterly and annual NSW HIV Strategy data reports; annual NSW Hepatitis B and C Strategies data reports; and annual NSW STI Strategy data reports.

Framework Support Programs to support the delivery of the NSW Sexual Health Promotion Framework - workforce development was undertaken through a series of Framework Support Programs facilitated by BRISE.

BRISE webinars, website, journal articles, conference presentations, study reports and literature reviews.

BRISE deliverables are tailored annually through a work plan.

\section{Research use}

The Ministry uses the findings to monitor receptive syringe sharing in accordance with NSW strategy targets for HIV, hepatitis B and hepatitis C. The report provides data to improve local needle and syringe program delivery and targeting by Local Health Districts.

The Ministry is using the findings from this formative research to develop a HIV testing campaign targeting heterosexuals, but which also indirectly covers 'straight MSM'.

The estimates were used to set key performance indicators in Local Health District Service Agreements and the NSW Safety and Quality Framework.

The study's focus on changes over time in community attitudes to biomedical HIV prevention provides an evidence base for implementation of new HIV prevention strategies.

The Ministry uses the expert advice and data to monitor and report progress of the NSW Strategies for HIV, STIs, hepatitis B and hepatitis C.

The Framework Support Programs (FSP) engaged HIV and sexual health workers in training through a series of webinars. Topics for the eight FSPs completed were: social marketing, youth services, out-of-home care, Aboriginal FSP, peer educator, access to condoms, primary care and sexual health in schools.

These activities increased dissemination of information, making research findings accessible.

The work plan provides flexibility for a mix of longer-term (up to 5-year) projects to be implemented, with the ability to respond quickly to emerging policy-relevant research priorities.

NSW = New South Wales; HIV = human immunodeficiency virus; Ministry = NSW Ministry of Health 
goals and targets of the NSW Sexually Transmissible Infections Strategy 2016-2020 and the NSW HIV Strategy 2016-2020. ${ }^{12,13}$ The framework is an integrated population-based prevention program to increase access to sexual health information, condoms and services for young people aged 15-29 years. To support the framework implementation, extensive workforce development was undertaken through a series of Framework Support Programs (FSP) facilitated by BRISE. A BRISE senior researcher codelivered training with the Ministry through a series of webinars, using the experience and expertise of sector leaders as key partners and bringing coworkers together across the state. This facilitated the development of strong and effective relationships within each FSP and helped increase the skills and confidence of the workforce. Eight programs were completed; more than 100 participants completed training including HIV and sexual health workers, Aboriginal health workers and key partners. In addition, 20 NSW Sexual Health Promotion Leaders across NSW were supported to drive the development and implementation of the sexual health promotion work.

\section{Summary}

BRISE is a coherent and integrated program that delivers policy-relevant research, strategic advice, capacity building and communications to support the implementation of NSW BBV and STI Strategy areas of prevention, testing and treatment. BRISE facilitates the coproduction of research, where researchers and policy makers are meaningfully involved in all stages of research priority setting and codesign from development to application, building an understanding of the way evidence is generated to allow for greater integration between research and use of evidence. BRISE undertakes research to address gaps for policy and practice, and has delivered tools to inform and monitor the population health response to BBVs and STIs in NSW.

\section{Acknowledgements}

The authors would like to acknowledge the Kirby Institute, the Centre for Social Research in Health, the NSW Ministry of Health and all partners who contributed to BRISE research projects for their continued resourcefulness and dedication to the BBV and STI response in NSW.

\section{Peer review and provenance}

Externally peer reviewed, commissioned.

\section{Competing interests}

None declared.

\section{Author contributions}

TG was responsible for the design, drafting, analysis of data, and editing of the manuscript. CP was responsible for drafting, providing analytical advice, reviewing and editing the manuscript. TD, $\mathrm{H}-\mathrm{MS}$ and $\mathrm{JH}$ were responsible for reviewing and editing the manuscript.

\section{References}

1. Milat AJ, King L, Bauman A. The Physical Activity, Nutrition and Obesity Research Group: fostering population health research in NSW. NSW Public Health Bull. 2011;22(1-2):13-4.

2. Thackway S, Campbell D, Loppacher T. A longterm, strategic approach to evidence generation and knowledge translation in NSW, Australia. Public Health Res Pract. 2017;27(1):e2711702.

3. Schmidt H-M, Power C, Bath N, Holden J. Getting the research policy-makers need in HIV, STIs and viral hepatitis. Australasian HIV and AIDS Conference; 2015 Sep 16-18; Brisbane [cited 2018 Jul 4]. p.77. Available from: ashm.blob.core.windows.net/ashmpublic/ ASHM\%202015_All\%20Abstracts.pdf

4. Oliver K, Innvar S, Lorenc T, Woodman J, Thomas J. A systematic review of barriers to and facilitators of the use of evidence by policymakers. BMC Health Serv Res. 2014; 14(1):2.

5. van Schalkwyk MC, Harris M. Translational health policy: towards an integration of academia and policy. J R Soc Med. 2018;111(1):15-7.

6. Moore D, Campbell D. Evidence Check: Increasing the use of research in policymaking. Sydney: NSW Ministry of Health and the Sax Institute; 2017 [cited 2018 Aug 30]. Available from: www.health.nsw.gov.au/research/ Documents/increasing-the-use-of-research.pdf

7. Campbell DM, Redman S, Jorm L, Cooke M, Zwi AB, Rychetnik L. Increasing the use of evidence in health policy: practice and views of policy makers and researchers. Aust New Zealand Health Policy. 2009;6(1):21.

8. Brownson RC, Fielding JE, Green LW. Building capacity for evidence-based public health: reconciling the pulls of practice and the push of research. Annu Rev Public Health. 2018;39:27-53.

9. Smits PA, Denis J-L. How research funding agencies support science integration into policy and practice: an international overview. Implement Sci. 2014;9(1):28.

10. NSW Department of Health. Promoting the generation and effective use of population health research in NSW: a strategy for NSW Health 2011-2015. Sydney: NSW Department of Health; 2010 [cited 2018 Jul 4]. Available from: www.health.nsw.gov.au/research/Publications/pophealth-res-strat.pdf 
11. Centre for Epidemiology and Evidence. Population Health Research Strategy 2018-2022. Sydney: NSW Ministry of Health; 2018 [cited 2018 Jul 4]. Available from: www.health.nsw.gov.au/research/Publications/researchstrategy-2018-2022.pdf

12. NSW Ministry of Health. NSW HIV Strategy 2016-2020. Sydney: NSW Ministry of Health; 2016 [cited 2018 Jul 4]. Available from: www.health.nsw.gov.au/endinghiv/ Publications/nsw-hiv-strategy-2016-2020.PDF

13. NSW Ministry of Health. NSW STI Strategy 2016-2020. Sydney: NSW Ministry of Health; 2016 [cited 2018 Jul 4]. Available from: www1.health.nsw.gov.au/pds/ ActivePDSDocuments/IB2016_005.pdf

14. NSW Ministry of Health. NSW Hepatitis B Strategy 2014-2020. Sydney: NSW Ministry of Health; 2014 [cited 2018 Jul 4]. Available from: www.health.nsw.gov.au/ hepatitis/Publications/hepatitisbstrategy.pdf

15. NSW Ministry of Health. NSW Hepatitis C Strategy 2014-2020. Sydney: NSW Ministry of Health; 2014 [cited 2018 Jul 4]. Available from: www.health.nsw.gov.au/ hepatitis/Publications/hepatitiscstrategy.pdf

16. NSW Ministry of Health. NSW Aboriginal Blood Borne Viruses and Sexually Transmissible Infections Framework 2016-2021. Sydney: NSW Ministry of Health; 2016 [cited $2018 \mathrm{Jul} 4$ ]. Available from: www1.health.nsw.gov.au/pds/ ActivePDSDocuments/IB2016_020.pdf
17. Geddes L, Iversen J, Maher L. New South Wales needle and syringe program enhanced data collection report 2017. Sydney: The Kirby Institute, University of NSW; 2017 [cited $2018 \mathrm{Jul} 4$ ]. Available from: www.brise.com. au/sites/default/files/documents/2017\%20NNEDC\%20 NSW\%20Report.pdf

18. Newman C, Persson A, de Wit J, Holt M, Callander D, Schmidt H-M, et al. BRISE StraightMSM Study: understanding expert views on defining and reaching heterosexually-identified men who have sex with men for health promotion and care (short report). Sydney: University of NSW; 2016 [cited 2018 Jul 4]. Available from: csrh.arts.unsw.edu.au/media/CSRHFile/BRISE_ StraightMSM_Study_short_report.pdf

19. The Kirby Institute. 2017 estimates and projections of the Hepatitis C virus epidemic in NSW: summary report. Sydney: The Kirby Institute, University of NSW; 2017 [cited $2018 \mathrm{Jul}$ 4]. Available from: www.brise.com. au/system/files/documents/the_kirby_institute2017_ estimates_and_projections_of_the_hepatitis_c.pdf

20. Lea T, Kolstee J, Murphy D, Ellard J, Schmidt H-M, Crawford D, et al. Changing attitudes to and engagement with biomedical HIV prevention by gay and bisexual men: key findings from the PrEPARE Project 2017. Sydney: Centre for Social Research in Health, University of NSW; 2017 [cited $2018 \mathrm{Jul}$ 4]. Available from: unsworks.unsw. edu.au/fapi/datastream/unsworks:48836/bin6919301153eb-4ae1-b119-e3767d45efb5?view=true

\section{Copyright: (c)}

(C) 2018 Gordon et al. This article is licensed under the Creative Commons Attribution-NonCommercial-ShareAlike 4.0 International Licence, which allows others to redistribute, adapt and share this work non-commercially provided they attribute the work and any adapted version of it is distributed under the same Creative Commons licence terms. See: www.creativecommons.org/licenses/by-nc-sa/4.0/ 